\title{
On-farm estimation of energy balance in dairy cows using only frequent body weight measurements and body condition score
}

\author{
V. M. Thorup,${ }^{\star 1}$ D. Edwards, $†$ and N. C. Friggens $¥ \S$ \\ *Department of Animal Science, University of Aarhus, Foulum, 8830 Tjele, Denmark \\ †Department of Genetics and Biotechnology, University of Aarhus, Foulum, 8830 Tjele, Denmark \\ †INRA, UMR 791 Modélisation Systémique Appliquée aux Ruminants, and \\ §AgroParisTech, UMR 791 Modélisation Systémique Appliquée aux Ruminants, 16 rue Claude Bernard, 75005 Paris, France
}

\begin{abstract}
Precise energy balance estimates for individual cows are of great importance to monitor health, reproduction, and feed management. Energy balance is usually calculated as energy input minus output $\left(\mathrm{EB}_{\text {inout }}\right)$, requiring measurements of feed intake and energy output sources (milk, maintenance, activity, growth, and pregnancy). Except for milk yield, direct measurements of the other sources are difficult to obtain in practice, and estimates contain considerable error sources, limiting on-farm use. Alternatively, energy balance can be estimated from body reserve changes $\left(\mathrm{EB}_{\text {body }}\right)$ using body weight (BW) and body condition score (BCS). Automated weighing systems exist and new technology performing semi-automated body condition scoring has emerged, so frequent automated BW and BCS measurements are feasible. We present a method to derive individual $\mathrm{EB}_{\text {body }}$ estimates from frequently measured $\mathrm{BW}$ and BCS and evaluate the performance of the estimated $\mathrm{EB}_{\text {body }}$ against the traditional $\mathrm{EB}_{\text {inout }}$ method. From 76 Danish Holstein and Jersey cows, parity 1 or $2+$, on a glycerol-rich or a whole grain-rich total mixed ration, BW was measured automatically at each milking. The $\mathrm{BW}$ was corrected for the weight of milk produced and for gutfill. Changes in BW and BCS were used to calculate changes in body protein, body lipid, and $\mathrm{EB}_{\text {body }}$ during the first $150 \mathrm{~d}$ in milk. The $\mathrm{EB}_{\text {body }}$ was compared with the traditional $\mathrm{EB}_{\text {inout }}$ by isolating the term within $\mathrm{EB}_{\text {inout }}$ associated with most uncertainty; that is, feed energy content $($ FEC $) ; \mathrm{FEC}=\left(\mathrm{EB}_{\text {body }}+\right.$ EMilk + EMaintenance + Eactivity)/dry matter intake, where the energy requirements are for milk produced (EMilk), maintenance (EMaintenance), and activity (EActivity). Estimated FEC agreed well with FEC values derived from tables (the mean estimate was $0.21 \mathrm{MJ}$ of effective energy $/ \mathrm{kg}$ of dry matter or $2.2 \%$ higher than the mean table value). Further, the FEC profile did not suggest
\end{abstract}

Received June 17, 2011.

Accepted November 29, 2011.

${ }^{1}$ Corresponding author: vivim.thorup@agrsci.dk systematic bias in $\mathrm{EB}_{\text {body }}$ with stage of lactation. The $\mathrm{EB}_{\text {body }}$ estimated from daily $\mathrm{BW}$, adjusted for milk and meal-related gutfill and combined with frequent BCS, can provide a successful tool. This offers a pragmatic solution to on-farm calculation of energy balance with the perspective of improved precision under commercial conditions.

Key words: energy balance, body condition score, body weight, modeling

\section{INTRODUCTION}

The notion that early lactation is associated with decreased health and reproduction is widely accepted (Ingvartsen et al., 2003). Increased levels of digestive and locomotion disorders in early lactation and delayed reproduction have been linked with more lengthy and severe periods of negative energy balance; that is, greater body reserve mobilization (Frigo et al., 2010). Therefore, estimates of the dairy cow's energy balance are of great importance to monitor health, reproduction, and feed management. Traditionally, energy balance in dairy cows has been calculated as energy input minus energy output $\left(\mathbf{E B}_{\text {inout }}\right.$; Friggens et al., 2007a; Banos and Coffey, 2010). The $\mathrm{EB}_{\text {inout }}$ method requires that feed energy intake and energy expenditure (milk, maintenance, activity, growth, and pregnancy) are recorded, and with the exception of milk yield, direct measurements of these sources are difficult to obtain in practice. Further, these calculations contain considerable error (Ellis et al., 2006a,b). An alternative is to estimate energy balance from changes in body reserves $\left(\mathbf{E B}_{\text {body }}\right)$, which involves measurements of $\mathrm{BW}$ and BCS (Coffey et al., 2001; Tedeschi et al., 2006; Friggens et al., 2007b). Although measuring BW and BCS is feasible in practice, until recently the method was not very suitable for detecting short-term changes because of infrequent BW and BCS measurements. Infrequent measurements make it difficult to detect and reduce noise in the time series of measurements. Automated weighing systems (often in the milking parlor) have become commercially available, and new technology 
Table 1. Milk yield, milk fat, milk protein, DMI, and smoothed BW for the 76 cows grouped by breed and diet, based on 1,108 observations (SD in parentheses)

\begin{tabular}{llcccccc}
\hline Breed & Diet ${ }^{1}$ & $\mathrm{n}$ & $\begin{array}{c}\text { Milk yield } \\
(\mathrm{kg} / \mathrm{d})\end{array}$ & $\begin{array}{c}\text { Milk fat } \\
(\%)\end{array}$ & $\begin{array}{c}\text { Milk } \\
\text { protein }(\%)\end{array}$ & $\begin{array}{c}\text { DMI } \\
(\mathrm{kg} / \mathrm{d})\end{array}$ & $\begin{array}{c}\text { BW } \\
(\mathrm{kg})\end{array}$ \\
\hline Danish Holstein & TMR 1 & 34 & $34.4(7.8)$ & $3.5(0.5)$ & $3.2(0.3)$ & $19.2(3.6)$ & $559(66)$ \\
Danish Holstein & TMR 2 & 23 & $32.0(8.9)$ & $3.7(0.6)$ & $3.3(0.2)$ & $18.5(2.8)$ & $546(49)$ \\
Jersey & TMR 1 & 10 & $24.5(3.7)$ & $5.1(0.6)$ & $3.9(0.3)$ & $16.8(3.3)$ & $418(54)$ \\
Jersey & TMR 2 & 9 & $20.5(4.3)$ & $5.4(0.7)$ & $4.2(0.3)$ & $16.0(3.8)$ & $389(29)$ \\
\hline
\end{tabular}

${ }^{1}$ TMR 1 was a glycerol-rich diet (15\% of DM was glycerol, $7 \%$ was wheat bran and soybean meal); TMR 2 was a whole grain-rich diet (22\% of DM was whole grain $\mathrm{NaOH}$-treated wheat).

within the field of semi-automated body condition scoring has emerged (Halachmi et al., 2008; Bewley and Schutz, 2009; Azzaro et al., 2011). Consequently, fully automated, frequent BW and BCS measurements now seem within reach. For the dairy farmer, the ability to assess the energy balance for individual cows on-farm would be a very attractive management tool. Estimating $\mathrm{EB}_{\text {body }}$ from daily, noise-reduced BW measurements that are adjusted for milk and meal-related gutfill and that are combined with frequent BCS measurements could provide such a tool. This would be a pragmatic solution to on-farm calculation of the energy balance of individual cows that offers the perspective of a significant improvement in the precision of energy balance estimation.

The purposes were to (1) present a method for deriving $\mathrm{EB}_{\text {body }}$ estimates for individual cows from frequently measured BW and BCS, and (2) evaluate the performance of our $\mathrm{EB}_{\text {body }}$ method against the traditional $\mathrm{EB}_{\text {inout }}$ method.

\section{MATERIALS AND METHODS}

\section{Cows and Experimental Procedures}

The data consisted of longitudinal measures of 76 cows through the first 150 DIM that allowed calculation of both $\mathrm{EB}_{\text {body }}$ and $\mathrm{EB}_{\text {inout. The }} 76$ cows were primiparous $(\mathrm{n}=51)$ or multiparous $(\mathrm{n}=25$, lactations 2 to 4) cows, calving from January to May 2008. Further, 57 cows were Danish Holsteins (DH) and 19 cows were Jerseys. All cows were loose-housed in a barn at the Danish Cattle Research Center (Tjele, Denmark) with an automatic milking system (VMS, Voluntary Milking System, DeLaval, Tumba, Sweden) and automatic feeding stations (Roughage Intake System, Insentec BV, Marknesse, the Netherlands). The data came from cows that were in a feeding experiment and had ad libitum access to 1 of 2 TMR: 44 cows were on a glycerol-rich diet (TMR 1: 15\% of DM was glycerol, $7 \%$ was wheat bran and soybean meal), and 32 were on a whole grain-rich diet (TMR 2: $22 \%$ of DM was whole grain $\mathrm{NaOH}$-treated wheat). The average performances of milk yield (MY), milk fat, milk protein, DMI, and smoothed BW of the cows grouped by breed and diet are in Table 1.

At each milking the cows were weighed automatically on a weighing platform (Bjerringbro Vægte, Bjerringbro, Denmark) installed in the VMS. Milk yield was recorded at each milking, and composite milk samples from all milkings in a 48-h period were taken and analyzed for fat, protein, and lactose content once weekly. The BCS was assessed every 2 wk by trained observers to the nearest quarter unit on a scale from 1 (emaciated) to 5 (obese; Ferguson et al., 1994).

All procedures involving animals were approved by the Danish Animal Experiments Inspectorate and complied with the Danish Ministry of Justice Law no. 382 (June 10, 1987) and Acts 739 (December 6, 1988) and 333 (May 19, 1990) concerning animal experimentation and care of experimental animals.

\section{Milk-Free and Meal-Related Gutfill-Free BW}

While the cow was standing on the weighing platform in the VMS, her BW was automatically recorded 6 times/s during the milking. For each VMS milking, the end-weight, or so-called milk-free BW $\left(\mathbf{B W}_{\mathrm{mf}}\right)$, was derived from the weighing platform data as follows. First, cleaning rules were applied to exclude artifacts. If the median BW during the milking was $<200 \mathrm{~kg}$, or if $>30 \%$ of the values were under a threshold of the median BW minus $75 \mathrm{~kg}$, all data obtained during that particular milking were excluded. Initial and final time intervals (i.e., when the cow was only partly on the weighing platform as she entered or left the VMS) were defined as intervals for which $>50 \%$ of the values were under the threshold; these were excluded from the data set for that particular cow. To obtain a simple and robust estimate of $\mathrm{BW}_{\mathrm{mf}}$, the remaining values were cubic spline-smoothed using 3 knots, and $\mathrm{BW}_{\mathrm{mf}}$ was defined as the final value in the remaining interval. This is illustrated in Figure 1.

An example of $\mathrm{BW}_{\mathrm{mf}}$ relative to DIM is shown in Figure 2. The noise in this time-series is mainly due to variation in gutfill associated with the temporal pat- 


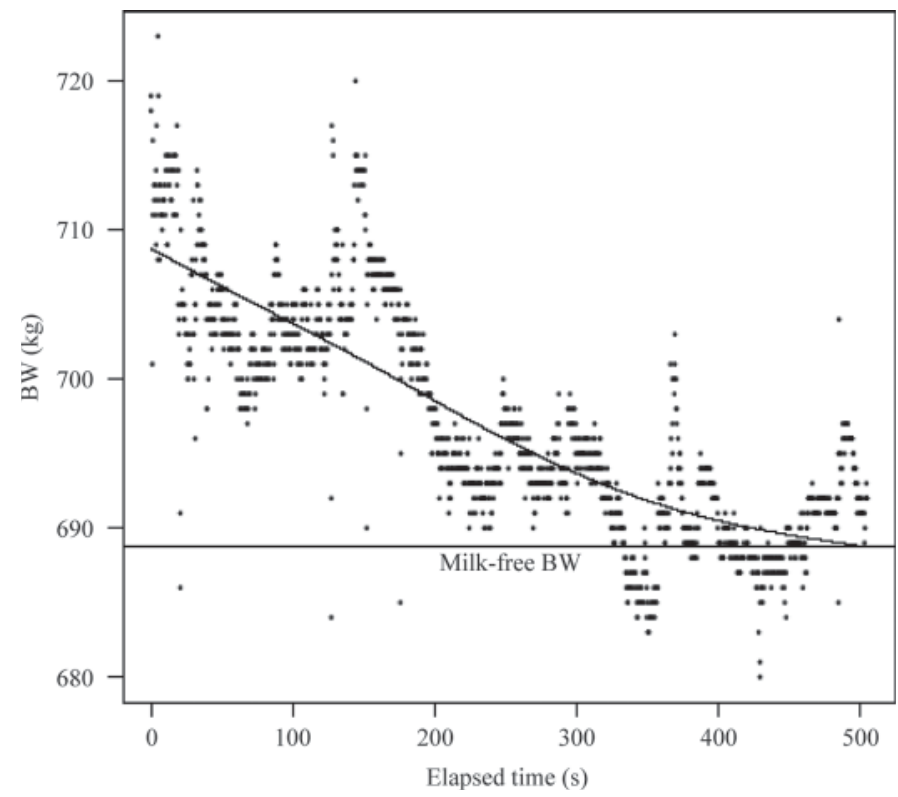

Figure 1. Example of BW $(\mathrm{kg})$ development (dots) relative to elapsed time during a single milking, illustrating how the milk-free BW (horizontal line) was derived as the end-point of cubic spline smoothing (line) of the raw weights.

tern of meals ingested by the cow (in systems with VMS there is no fixed relation between time of milking and times of feed distribution). Consequently, a meal-related gutfill-free BW $\left(\mathbf{B W}_{\text {gff }}\right)$ was derived from the $\mathrm{BW}_{\mathrm{mf}}$ for the first 150 DIM using the following logic. Gutfill (GF) can be considered as the sum of 2 components: a large meal-related component that is a function of the feed intake pattern in the preceding hours, and a smaller residual component remaining in the gut that is assumed constant on this time-scale. To eliminate the meal-related gutfill variation, $\mathrm{BW}_{\text {gff }}$ was derived from $\mathrm{BW}_{\mathrm{mf}}$ by quantile regression (Koenker and Hallock, 2001) using the $20 \%$ lower quantile of the distribution in a cubic spline function with nonequidistant knots, an example of which is in Figure 2. The lower $20 \%$ quantile was chosen because this is close to the proportion of residual GF to total GF found for normal diets (Martin and Sauvant, 2010b) and because, empirically, this provides a suitable offset where the fit is not perturbed by extreme outliers. In this process, if 2 consecutive $\mathrm{BW}_{\mathrm{mf}}$ differed by more than $200 \mathrm{~kg}$, then the lower weight was excluded. Using equidistant knots did not model the weight decline in early lactation well, therefore nonequidistant knots at 1, 12, 20,60,115, and 150 DIM were chosen, in accordance with Friggens and colleagues (2007a).

The BCS data were smoothed across lactation using natural cubic splines of degree 3 (Hastie and Tibshirani, 1990). An example of BCS observations and smoothed BCS curve for 1 cow relative to DIM is in Figure 3.

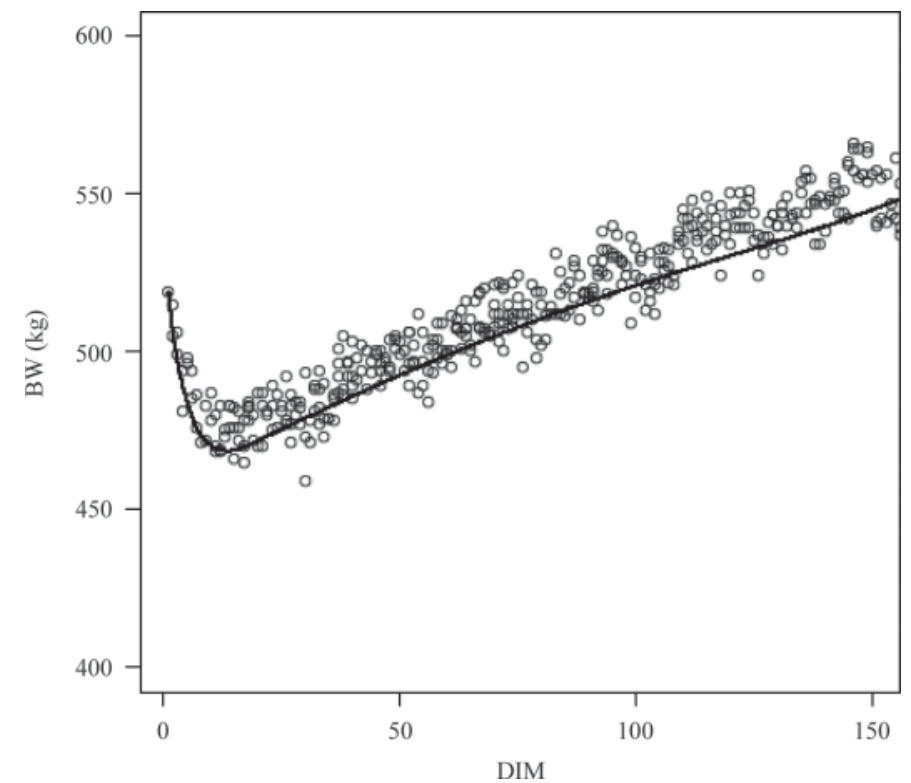

Figure 2. Example of milk-free BW $(\mathrm{kg})$ observations $(\bigcirc)$ and the smoothed (quantile regressed; see Materials and Methods section) meal-related gutfill-free BW (line) of 1 cow relative to DIM.

\section{Calculation of $E B_{\text {body }}$}

Because any discrepancy between energy inputs and outputs must be met by changes in body energy, $\mathrm{EB}_{\text {body }}$ $(\mathrm{MJ} / \mathrm{d})$ can be calculated from changes in body lipid (BL) and body protein (BP):

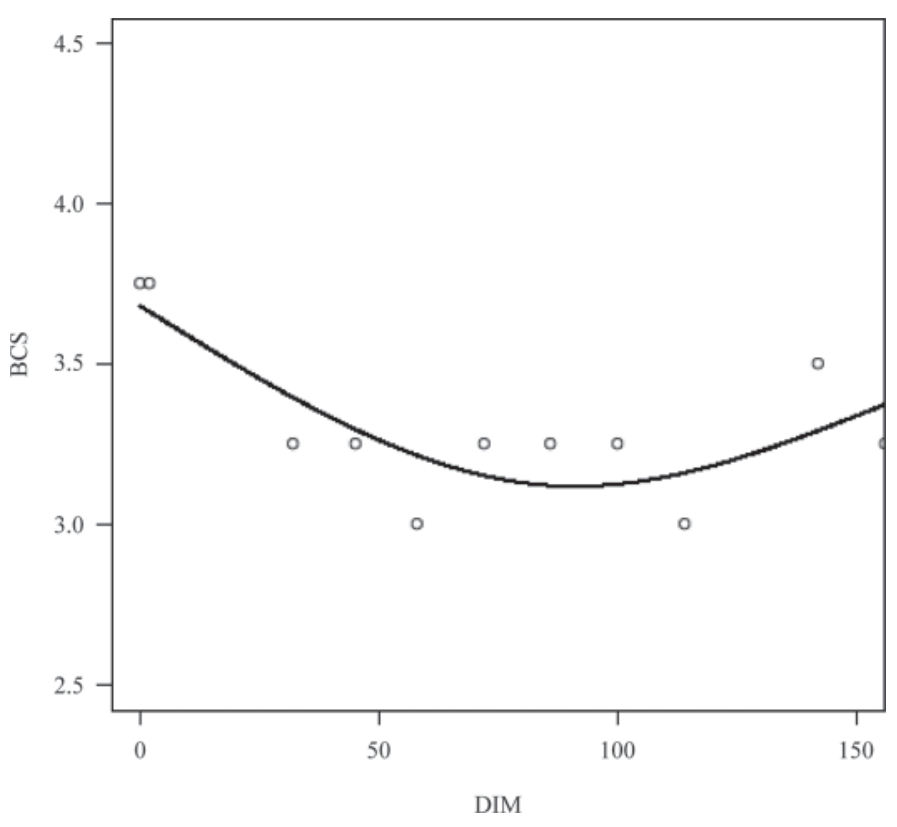

Figure 3. Example of BCS observations $(\bigcirc)$ and smoothed BCS (line) for 1 cow relative to DIM. 


$$
\mathrm{EB}_{\text {body }}=\mathrm{z} \times \Delta \mathrm{BL}+\mathrm{y} \times \Delta \mathrm{BP},
$$

where $\Delta \mathrm{BL}$ is the rate of change in $\mathrm{BL}(\mathrm{kg} / \mathrm{d}) ; \Delta \mathrm{BP}$ is the rate of change in $\mathrm{BP}(\mathrm{kg} / \mathrm{d}) ; \mathrm{z}$ is the energy associated with BL change $(\mathrm{MJ} / \mathrm{kg})$; and $\mathrm{y}$ is the energy associated with $\mathrm{BP}$ change $(\mathrm{MJ} / \mathrm{kg})$.

It has been shown that BL $(\mathrm{kg})$ can be estimated from BCS (Wright and Russel, 1984):

$$
\mathrm{BL}=\mathrm{EBW} \times(\mathrm{a}+\mathrm{b} \times \mathrm{BCS}),
$$

where $\mathbf{E B W}$ is empty BW, and a ( $\mathrm{kg}$ of lipid/ $\mathrm{kg}$ of $\mathrm{EBW}$ ) and $\mathrm{b}$ ( $\mathrm{kg}$ of lipid/kg of EBW/unit of BCS) are constants relating BCS to body fatness. Thus, the rate of change in $\mathrm{BL}$ can be estimated from the change in $\mathrm{EBW}(\boldsymbol{\Delta E B W})$ and the change in $\mathrm{EBW} \times \mathrm{BCS}$ $[\Delta(\mathrm{EBW} \times \mathrm{BCS})]$ as

$$
\Delta \mathrm{BL}=\mathrm{a} \times \Delta \mathrm{EBW}+\mathrm{b} \times \Delta(\mathrm{EBW} \times \mathrm{BCS}) ;
$$

BP $(\mathrm{kg})$ is assumed a constant proportion, $\mathrm{k}$, of lipidfree $\mathrm{EBW}$ (LFEBW, kg):

$$
\mathrm{BP}=\mathrm{k} \times \mathrm{LFEBW},
$$

Given that the sum of LFEBW and BL is EBW, and then substituting equation [3] for $\triangle \mathrm{BL}$ :

$$
\begin{gathered}
\Delta \mathrm{BP}=\mathrm{k} \times(\Delta \mathrm{EBW}-\Delta \mathrm{BL}), \\
\begin{aligned}
\Delta \mathrm{BP}= & \mathrm{k} \times[(1-\mathrm{a}) \times \Delta \mathrm{EBW}-\mathrm{b} \\
& \times \Delta(\mathrm{EBW} \times \mathrm{BCS})] .
\end{aligned}
\end{gathered}
$$

Substituting equations [3] and [5] in equation [1] gives

$$
\begin{aligned}
& \mathrm{EB}_{\text {body }}(\mathrm{MJ} / \mathrm{d})=\mathrm{z} \times[\mathrm{a} \times \Delta \mathrm{EBW}+\mathrm{b} \\
& \times \Delta(\mathrm{EBW} \times \mathrm{BCS})]+\mathrm{y} \times \mathrm{k} \times[(1-\mathrm{a}) \\
& \times \Delta \mathrm{EBW}-\mathrm{b} \times \Delta(\mathrm{EBW} \times \mathrm{BCS})]
\end{aligned}
$$

The constants $\mathrm{k}(0.2224 \mathrm{~kg} / \mathrm{kg})$, y $(13.5 \mathrm{MJ} / \mathrm{kg}$ of mobilized and $50.0 \mathrm{MJ} / \mathrm{kg}$ of deposited protein), and z (39.6 MJ $/ \mathrm{kg}$ of mobilized and $56.0 \mathrm{MJ} / \mathrm{kg}$ of deposited lipid) can be regarded as generic, and the energy units used are effective energy (EE; Emmans, 1994). In this system, $1 \mathrm{MJ}$ of EE supply has the same energy value as 1 MJ of lipid loss from the body. Thus, the EE values assigned to feeds are directly equivalent to the energy requirements of the animal. Because the constants $\mathrm{y}$ and $\mathrm{z}$ depend on whether protein and fat are being mobilized or deposited, the lactation period was partitioned for simplicity into 3 periods. We assumed that during the first period (early lactation: d 0 to 28), lipid and protein are both mobilized (Cammell et al., 2000); during the second period (peak lactation: d 29 to 70), lipid is mobilized and protein may be deposited; and finally during the third period (mid lactation: $\mathrm{d} 71$ to 150), both lipid and protein are being deposited. The constants $\mathrm{a}$ and $\mathrm{b}$ were assumed to have the values 0.05 $\mathrm{kg}$ of lipid $/ \mathrm{kg}$ of EBW and $0.10 \mathrm{~kg}$ of lipid $/ \mathrm{kg}$ of EBW/ unit of BCS; details of estimation are given by Friggens et al. (2007b).

\section{Derivation of EBW from $B W$}

The difference between BW and EBW is assumed to be primarily due to fill of the gut, udder, and uterus. Udder fill is accounted for by the derivation $\mathrm{BW}_{\mathrm{mf}}$, uterine fill we assume negligible, because this study focuses on the first 150 DIM, and this leaves GF to be adjusted for. The adjustment for GF is greatly facilitated by having accounted for meal-related variation in gutfill ( $\mathrm{BW}_{\mathrm{gff}}$, described above), so this leaves residual gutfill to be corrected for, which is described below. Martin and Sauvant (2010b) showed that, across a wide range of feeding conditions, the daily trend in decay in residual gutfill (dRGF/dt) can be described as follows:

$$
\mathrm{dRGF} / \mathrm{dt}=\mathrm{FMI}-\mathrm{f} \times(\mathrm{GF}-\delta \times \mathrm{LFEBW}), \quad[7] .
$$

where RGF is residual gutfill ( $\mathrm{kg}$ ), FMI is daily fresh matter intake $(\mathrm{kg} / \mathrm{d}), \mathbf{f}$ is the fractional daily rate of removal of digestive contents, GF is the meal-related $\mathrm{GF}(\mathrm{kg})$, and $\boldsymbol{\delta}$ is the RGF as a proportion of LFEBW $(\mathrm{kg} / \mathrm{kg})$.

Equation [7] contains intake, which is inconvenient because this study aimed to derive an energy balance measure that did not require measurement of intake. Using an approximation that has trivial consequences on the calculations permits the removal of intake from the calculation. In the situation where meal-related GF has been removed and daily intake is stable, by definition, GF is constant and thus dRGF/dt is 0 , so

$$
\begin{gathered}
\mathrm{FMI}=\mathrm{f} \times(\mathrm{RGF}-\delta \times \mathrm{LFEBW}), \\
\mathrm{RGF} / \mathrm{LFEBW}=\mathrm{FMI} /(\mathrm{f} \times \mathrm{LFEBW})+\delta .
\end{gathered}
$$

This shows that, at a given stable level of intake, RGF is a constant proportion of LFEBW. Further, simulation across a wide range of FMI (9 to $54 \mathrm{~kg} / \mathrm{d}$ ) showed that the variation in the value of RGF/LFEBW has a very small effect on estimation of EBW. For example, when estimates of EBW using a constant value of RGF/LFEBW of 0.26 are compared with estimates of EBW throughout lactation calculated using a lacta- 
tion curve of FMI increasing from 25 to $55 \mathrm{~kg} / \mathrm{d}$ at peak before tailing off to $20 \mathrm{~kg} / \mathrm{d}$ (Friggens et al., 1998), the maximum discrepancy was just $3 \%$ in EBW. Thus, we believe it is an acceptable approximation to assume that RGF/LFEBW $(\mathrm{kg} / \mathrm{kg})$, hereafter called $\mathrm{g}$, is constant, and assumed 0.26. Given g, EBW can be calculated as

$$
\begin{gathered}
\mathrm{EBW}=\mathrm{BW}_{\mathrm{gff}}-\mathrm{g} \times \mathrm{LFEBW}= \\
\mathrm{BW}_{\mathrm{gff}}-\mathrm{g} \times(\mathrm{EBW}-\mathrm{BL}) .
\end{gathered}
$$

Substituting equation [2] in equation [9]:

$$
\begin{aligned}
\mathrm{EBW} & =\mathrm{BW}_{\mathrm{gff}}-\mathrm{g} \times\{\mathrm{EBW}-[\mathrm{EBW} \times(\mathrm{a}+\mathrm{b} \\
\times \mathrm{BCS})]\} & =\mathrm{BW}_{\mathrm{gff}} /[1+\mathrm{g} \times(1-\mathrm{a}-\mathrm{b} \times \mathrm{BCS})] .
\end{aligned}
$$

\section{Model Evaluation}

Testing a traditional $\mathrm{EB}_{\text {inout }}$ calculation is usually done by comparing the weight change to the end of the lactation with the cumulated $\mathrm{EB}_{\text {inout }}$. This approach was not feasible with $\mathrm{EB}_{\text {body }}$, as this would imply having $\mathrm{BW}$ on both sides of the equation, making it a circular test. If $\mathrm{EB}_{\text {inout }}$ could be assumed error- and bias-free, then it would be logical to compare $\mathrm{EB}_{\text {body }}$ to $\mathrm{EB}_{\text {inout }}$ directly. It has been shown that this assumption does not hold (Ellis et al., 2006a,b). To deal with this, the uncertainty in $\mathrm{EB}_{\text {inout }}$ was isolated on one side of the equation and this value was estimated, namely the feed energy content (FEC). When feed composition is not altered, and ignoring possible intake effects on digestibility (FEC is largely unaffected by level of feeding when expressed in EE units; Emmans, 1994), the true FEC value is not expected to change with DIM. Thus, to evaluate the $\mathrm{EB}_{\text {body }}$ method, systematic trends in FEC were calculated from $\mathrm{EB}_{\text {body }}$ and $\mathrm{EB}_{\text {inout }}$ components, relative to DIM. The manipulation to derive calculated FEC was as follows:

$$
\begin{gathered}
\mathrm{EB}_{\text {inout }}=\text { EIntake }-(\text { EMilk } \\
+ \text { EMaintenance }+ \text { EActivity }),
\end{gathered}
$$

where EIntake is feed energy intake, EMilk is energy required for MY, EMaintenance is energy required for maintenance, and EActivity is energy required for activity. And, assuming that $\mathrm{EB}_{\text {inout }}=\mathrm{EB}_{\text {body }}$, then

$$
\begin{gathered}
\mathrm{EB}_{\text {body }}+\text { EMilk }+ \text { EMaintenance } \\
+ \text { EActivity }=\text { EIntake }
\end{gathered}
$$

Because EIntake $=$ FEC $\times$ DMI, then
FEC $(\mathrm{MJ}$ of EE/kg of DMI $)=\left(\mathrm{EB}_{\text {body }}+\right.$ EMilk

$$
+ \text { EMaintenance + EActivity)/DMI, }
$$

where $\mathrm{EB}_{\text {body }}$ is calculated according to equation [1], and EMilk, EMaintenance, and EActivity are defined below using the EE system (Emmans, 1994). The above test to compare $\mathrm{EB}_{\text {body }}$ and $\mathrm{EB}_{\text {inout }}$, using equation [11], would be valid using other energy systems, provided that there was equivalence between supply and expenditure energy units:

$$
\begin{gathered}
\text { EMilk }(\text { MJ of EE/d) = EFat } \\
+ \text { EProtein }+ \text { ELactose }
\end{gathered}
$$

where EFat $=\mathrm{MY} \times($ milk fat percentage $/ 100) \times 56$, and is the energy required to produce $1 \mathrm{~kg}$ of milk fat $(\mathrm{MJ}$ of $\mathrm{EE} / \mathrm{kg}) ;$ EProtein $=\mathrm{MY} \times($ milk protein percentage $/ 100) \times 33$, and is the energy required to produce $1 \mathrm{~kg}$ of milk protein (MJ of EE $/ \mathrm{kg}$ ); and ELactose $=\mathrm{MY} \times($ milk lactose percentage $/ 100) \times 18$, and is the energy required to produce $1 \mathrm{~kg}$ of milk lactose $(\mathrm{MJ}$ of $\mathrm{EE} / \mathrm{kg}$ ). These energy values are in accordance with Emmans and Kyriazakis (2001).

$$
\begin{gathered}
\text { EMaintenance }(\mathrm{MJ} \mathrm{EE} / \mathrm{d})= \\
1.63 \times\left(\mathrm{BP} / \mathrm{BPmat}^{0.27}\right),
\end{gathered}
$$

where BPmat is body protein at maturity. For parity 3 and older cows, BPmat was assumed $0.2224(\mathrm{~kg} / \mathrm{kg})$ $\times$ LFEBW $(\mathrm{kg}$; calculated from EBW standardized to BCS 3) at 112 DIM. Parity 2 cows were assumed $94 \%$ of mature size, and parity 1 cows $85 \%$ of mature size, at the same DIM (Friggens et al., 2007a).

$$
\text { EActivity }(\mathrm{MJ} \text { of } \mathrm{EE} / \mathrm{d})=0.01 \times \mathrm{BW}_{\text {gff }} \text {. }
$$

The calculations of EIntake, EMilk, EMaintenance, and EActivity have been described in detail by Friggens et al. (2007a). For calculating $\mathrm{EB}_{\text {inout }}$ in the present study, no smoothing was applied to the base observations of DMI, MY, or milk composition for the purpose of deriving EMilk, EMaintenance, EActivity, and FEC.

\section{Statistical Analysis}

All data manipulation was performed using the $\mathrm{R}$ software (R Development Core Team, 2011). Before calculating $\mathrm{EB}_{\text {body }}$ averages, observations of EBW changes exceeding more than -7.5 or $+5 \mathrm{~kg} / \mathrm{d}$ were excluded (affecting 87 out of 10,497 observations).

The FEC was calculated only for days on which information on DMI, MY, and milk components was 
available; this data set contained 1,108 observations. The FEC was tested using PROC MIXED in SAS with the Kenward-Roger degree-of-freedom procedure due to unbalanced data because of missing observations (Littel et al., 2002). A full model initially included breed, parity, diet, DIM, and the 2-way interactions. One cow was excluded from analysis; otherwise, the model would not converge:

$$
\begin{gathered}
\text { FEC }_{\mathrm{ijklm}}=\mu+\text { breed }_{\mathrm{i}}+\text { parity }_{\mathrm{j}}+\text { diet }_{\mathrm{k}}+\mathrm{cDIM}_{\mathrm{m}} \\
+\left(\mathrm{cDIM}_{\mathrm{m}} \times \text { breed }_{\mathrm{i}}\right)+\left(\mathrm{cDIM}_{\mathrm{m}} \times \text { parity }_{\mathrm{j}}\right) \\
+\left(\mathrm{cDIM}_{\mathrm{m}} \times \operatorname{diet}_{\mathrm{k}}\right)+\text { cow }_{\mathrm{l}}+\varepsilon_{\mathrm{ijklm}}
\end{gathered}
$$

where breed ( $\mathrm{i}=\mathrm{DH}$, Jersey), parity $(\mathrm{j}=1,2+)$, and $\operatorname{diet}(\mathrm{k}=\mathrm{TMR} 1$, TMR 2$)$ were fixed effects, and cDIM was a continuous time variable $(\mathrm{m}=-75, \ldots, 75)$ centered on DIM $=75$ to minimize correlations between slope and intercept parameters, cow $(l=1, \ldots$, $75)$ was included as a random effect, and $\varepsilon_{\mathrm{ijklm}}$ was the random residual error term associated with the ijklmth observation. To take into account the correlation from the same cow, $\varepsilon_{\mathrm{ijklm}}$ was assumed to follow a multivariate normal distribution for each cow with a Toeplitz covariance structure (Littel et al., 2002). Stepwise removal of nonsignificant effects reduced the model to the following (the main effect of cDIM was excluded to allow direct testing, on each diet, for slopes different from zero):

$$
\begin{aligned}
\mathrm{FEC}_{\mathrm{iklm}}=\mu & + \text { breed }_{\mathrm{i}}+\left(\mathrm{cDIM}_{\mathrm{m}} \times \operatorname{diet}_{\mathrm{k}}\right) \\
& +\operatorname{cow}_{\mathrm{l}}+\varepsilon_{\mathrm{iklm}} .
\end{aligned}
$$

\section{RESULTS}

Examples of $\mathrm{EB}_{\text {body }}$ trajectories relative to DIM for 4 individual cows are illustrated in Figure 4. The small disruptions at 28 and 70 DIM are caused by the assumed transition points of BL and BP between mobilization and deposition.

The average $\mathrm{EB}_{\text {body }}$ trajectories relative to DIM for cows grouped by breed, parity, and diet and the standard deviation are in Figure 5. Visual inspection suggested that in early lactation, DH cows had a greater negative energy balance than Jersey cows, but recovered more quickly such that Jerseys appeared to have a lower $\mathrm{EB}_{\text {body }}$ than DH from 30 DIM onward (Figure $5 \mathrm{~A})$. In early lactation, multiparous cows seemed to be in more negative $\mathrm{EB}_{\text {body }}$ than primiparous cows, but no consistent differences were observed between parities later in lactation (Figure 5B). With respect to diet, cows on TMR 1 appeared to start in a more negative
$\mathrm{EB}_{\text {body }}$ than TMR 2, but from 50 DIM on, no consistent differences were observed between diets (Figure $5 \mathrm{C})$. The standard deviation of $\mathrm{EB}_{\text {body }}$ relative to DIM is in Figure 5D, providing a measure of the variation between individuals.

We evaluated $\mathrm{EB}_{\text {body }}$ relative to Emilk output and DMI in the form of estimated FEC. Parity had no significant effect on FEC. Regarding breed, Jerseys had a significantly higher FEC $(9.74 \pm 0.10 \mathrm{MJ}$ of $\mathrm{EE} / \mathrm{kg}$ of $\mathrm{DM})$ than $\mathrm{DH}$ cows $(9.18 \pm 0.11 \mathrm{MJ}$ of $\mathrm{EE} / \mathrm{kg}$ of DM; t-value $=-5.09, P<0.0001)$. Here, it is noteworthy that Jerseys had a $2.45 \mathrm{~kg}$ (corresponding to $13 \%$ ) lower DMI than DH cows (Table 1). A significant diet by DIM interaction was observed for FEC. As shown in Figure 6, for TMR 2, a highly significant effect (tvalue $=-3.86, P<0.0001$ ) was found for DIM, which decreased FEC by $0.007 \mathrm{MJ}$ of $\mathrm{EE} / \mathrm{kg}$ of $\mathrm{DM}$ per day. For TMR 1, the effect of DIM on FEC was significant (t-value $=-2.00, P=0.05)$, decreasing FEC by 0.003 MJ of EE/kg of DM per day. The FEC calculated from feed composition and table values were similar for the 2 diets: $9.2 \mathrm{MJ}$ of EE/ $\mathrm{kg}$ of DM for TMR 1 and $9.3 \mathrm{MJ}$ of EE $/ \mathrm{kg}$ of DM for TMR 2, which agreed well with the average $9.46 \mathrm{MJ}$ of EE/kg of DM estimated from our analysis. The random animal effect on FEC accounted for $12.8 \%$ of the total variability in the data.

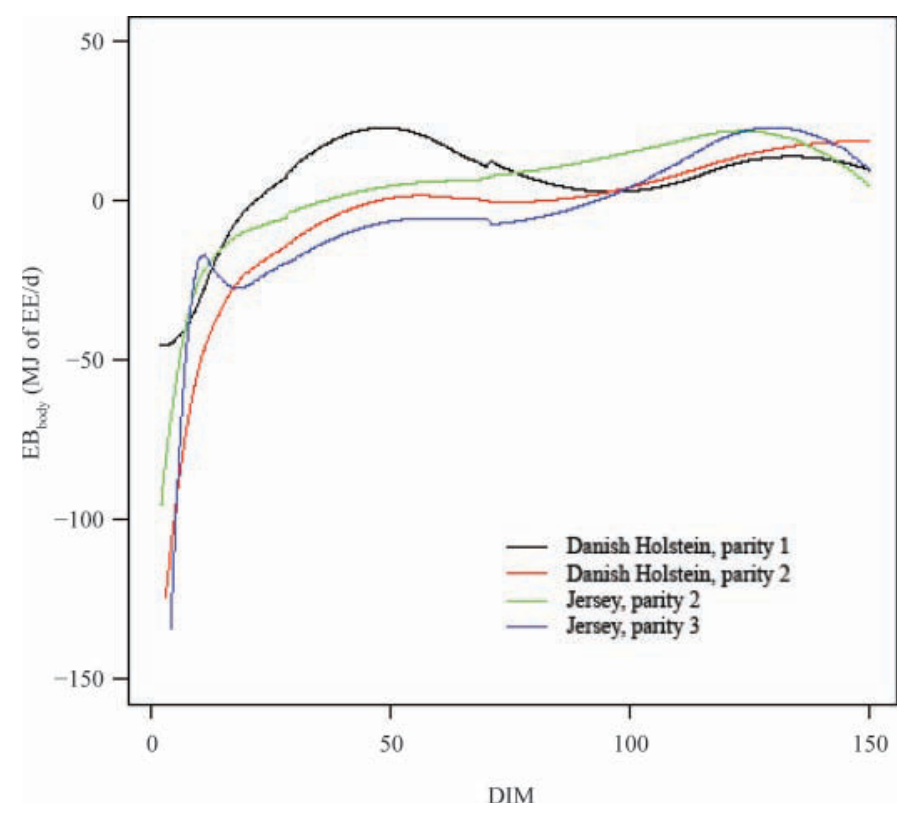

Figure 4. Examples of energy balance $\left[\mathrm{EB}_{\text {body }}\right.$; $\mathrm{MJ}$ of effective energy (EE)/d] for 4 cows relative to DIM. Color version available in the online PDF. 
A
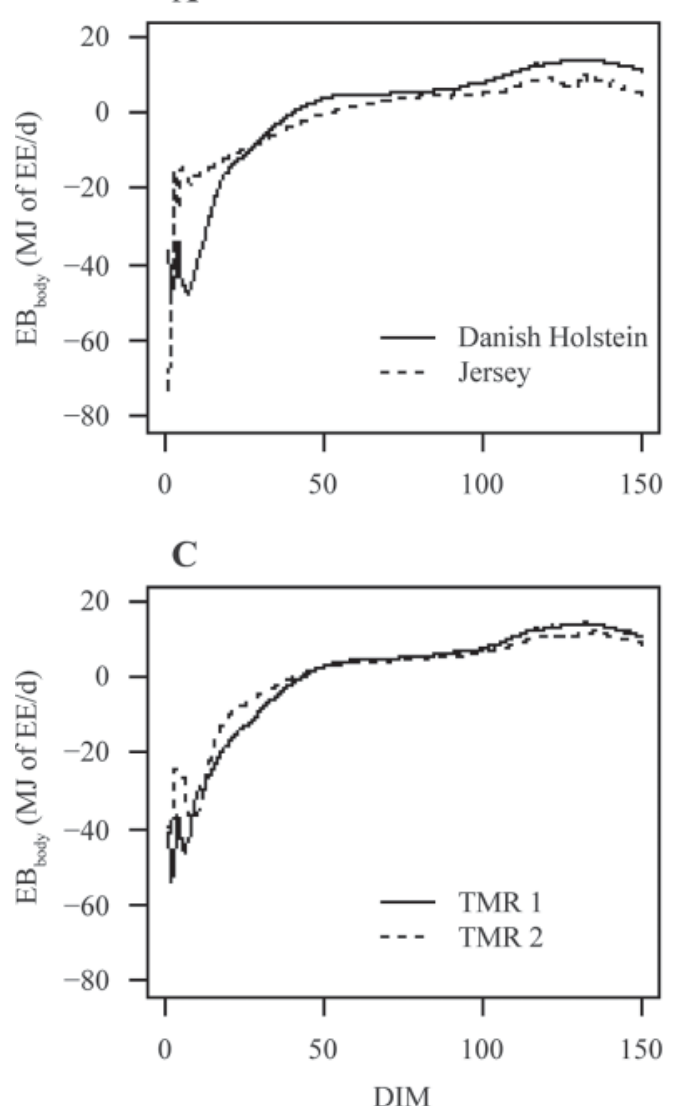
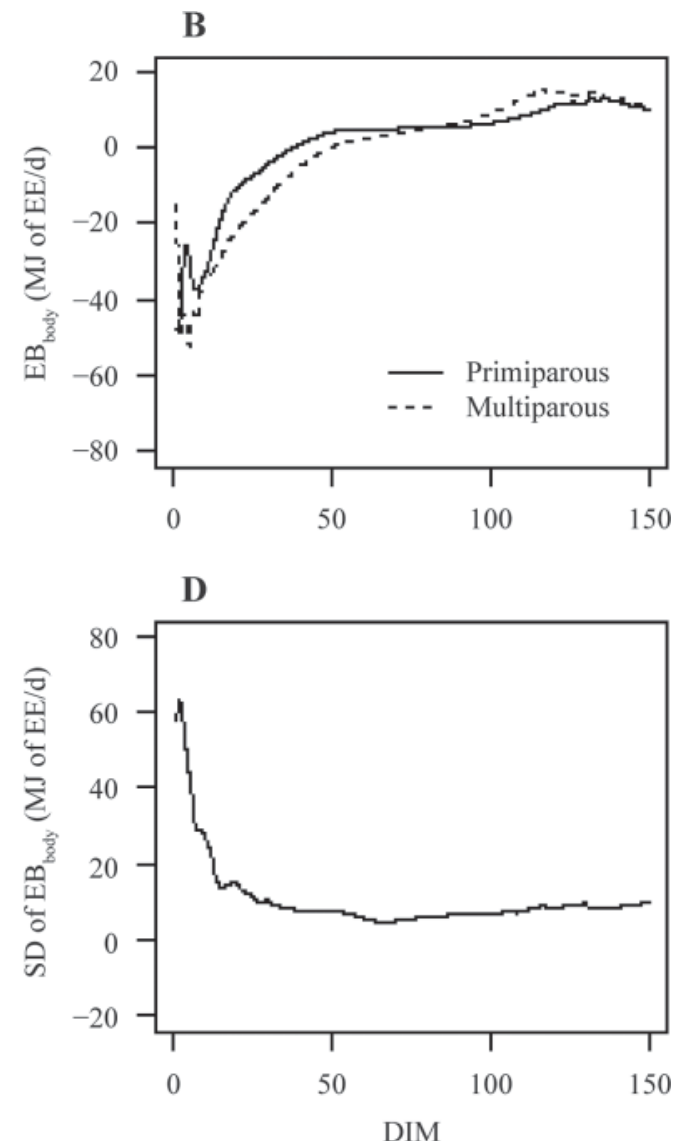

Figure 5. Average energy balance $\left[\mathrm{EB}_{\text {body }}\right.$; MJ of effective energy (EE)/d] relative to DIM for 76 cows grouped by (A) breed, (B) parity, (C) diet, and (D) standard deviation.

\section{DISCUSSION}

The $\mathrm{EB}_{\text {body }}$ curves relative to DIM for the different breeds (Figure 5A) and parities (Figure 5B) compare well with other studies (Oldenbroek, 1988; Friggens et al., 2007a; Banos and Coffey, 2010). Diet-related differences in energy balance (Figure 5C) have been reported (van Knegsel et al., 2007). In evaluating the energy balance calculated from frequently measured BW measurements and BCS, we chose not to regress $\mathrm{EB}_{\text {body }}$ on $\mathrm{EB}_{\text {inout }}$ because such a regression would imply that $\mathrm{EB}_{\text {inout }}$ is closer to the true energy balance. Although $\mathrm{EB}_{\text {inout }}$ (NRC, 2001) was considered the gold standard in estimating EB, Ellis et al. (2006a) challenged the notion of $\mathrm{EB}_{\text {inout }}$ actually being the gold standard (when not using calorimetry) by showing that with this traditional EB model, predicted BW differed significantly from observed values, and BW tended to be increasingly overpredicted with progressing lactation. Because of these findings, an alternative approach was chosen for evaluating $\mathrm{EB}_{\text {body }}$, a "proof by induction" approach. This approach recognizes that the main uncertainty in calculating $\mathrm{EB}_{\text {inout }}$ relates to the estimation of $\mathrm{FEC}$, which is usually derived from tabulated values based on feed ingredient composition and assumed digestibilities. Small errors in the assumed FEC value rapidly accumulate to produce the type of error identified by Ellis et al. (2006a). We chose to rearrange the equation linking $\mathrm{EB}_{\text {body }}$ and $\mathrm{EB}_{\text {inout }}$ to isolate the $\mathrm{FEC}$ term; that is, estimate FEC from $\mathrm{EB}_{\text {body }}$ plus energy outputs in milk and maintenance (as detailed in the Materials and Methods section). Thus, estimates of FEC were obtained relative to DIM (Figure 6). Feed composition did not change, so a simple hypothesis for evaluating the $\mathrm{EB}_{\text {body }}$ method is that DIM should have no significant effect on FEC. This hypothesis assumes that there are no correlated changes in TMR ingredient composition (e.g., changes in silage composition as the collection progresses through the silage bunker), that changes in FEC due to variability in DMI were negligible (Emmans 1994), and that the accuracy of measurement of TMR intake (e.g., changes in proportion of feed spilled by the cows) did not change. A secondary hypothesis would be that parity should have no effect on FEC, 


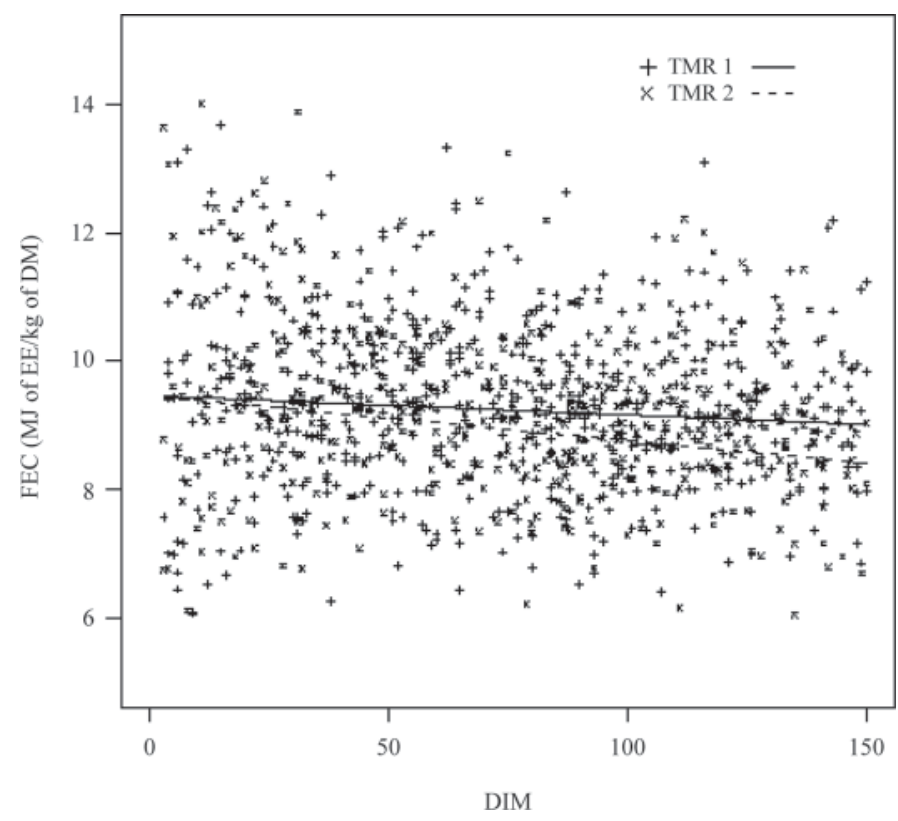

Figure 6. Estimated feed energy content (FEC; MJ of effective energy $(\mathrm{EE}) / \mathrm{kg}$ of $\mathrm{DM}$ ] relative to DIM for 75 cows grouped by diet. Lines represent the model $\mathrm{FEC}_{\mathrm{iklm}}=\mu+$ breed $_{\mathrm{i}}+\left(\mathrm{cDIM}_{\mathrm{m}} \times \operatorname{diet}_{\mathrm{k}}\right)$ $+\operatorname{cow}_{\mathrm{l}}+\varepsilon_{\mathrm{iklm}}$.

and breed should have little or no effect on FEC. Breed effects could be envisaged due to factors such as between-breed differences in distribution of body fat between subcutaneous and internal fat depots affecting the coefficients relating BCS to body fatness, although such effects are likely to be small (Wright and Russel, 1984; Friggens et al., 2007b).

Breed had a small effect and parity had no significant effect on FEC. This is an important result because substantial differences existed in BW and performance between the breeds represented in this study (Table 1). Therefore, this finding indicates that the $\mathrm{EB}_{\text {body }}$ method is robust to large differences in size and performance. The finding that the estimated FEC was higher for Jersey cows would agree with the finding that Jerseys have greater digestive efficiency and lower intakes compared with larger breeds (Ingvartsen and Weisbjerg, 1993), or it could be due to inherent breed differences in fat depots. With regard to the effect of DIM on FEC estimates, FEC showed a significant decline relative to DIM, especially on TMR 2 (Figure 6). Such a decline could be explained by deterioration in forage digestibility with time, or a progressive increase in feed wastage as a proportion of intake. Alternatively, it could be a bias in the $\mathrm{EB}_{\text {body }}$ method; for example, if systematic changes occurred in RGF with DIM, although simulation of changes in RGF had only a very minor effect on estimation of EBW, and this would not explain the difference between TMR in this effect. Another possi- bility, raised by Ellis et al. (2006b), is that bias related to stage of lactation exists in estimation of maintenance energy requirements. Regardless of the cause, this DIM effect on FEC accounted for only a very small proportion $(5.3 \%)$ of the total variability in the data. Further, the average estimated $\mathrm{FEC}$ value $(9.46 \mathrm{MJ}$ of $\mathrm{EE} / \mathrm{kg}$ of $\mathrm{DM}$ ) was very similar to the table values for both diets (9.2 and $9.3 \mathrm{MJ}$ of $\mathrm{EE} / \mathrm{kg}$ of $\mathrm{DM}$ ), which is well within the range of error of estimating FEC from feed table estimates of digestibility (Ellis et al., 2006a). Thus, using this "test by induction," the results suggest that the present method for calculating energy balance from frequently measured BW measurements and BCS (EB body $)$ is an adequate method for measuring energy balance on farm without having to measure DMI or MY. Interestingly, the use of BW and BCS for improving predictions of, for example, breeding values for body energy usage or intake requirements, is becoming increasingly accepted (Tedeschi et al., 2006; Banos and Coffey, 2010). Tedeschi et al. (2006) used 2 models (a model based on NRC and a model based on published data on BW and BCS changes) and 2 adjustment methods (1 method using first and last BCS values and 1 method using mean of weekly BCS values). They showed that adjusting ME- and MP-allowable milk production for changes in BCS improved the precision and accuracy of both models.

An alternative to using automated BCS is to simplify the model by assuming that BP change is zero, or assume a standard $\triangle \mathrm{BP}$. In mature cows after early lactation, it is reasonable to assume that $\triangle \mathrm{BP}$ is zero (Cammell et al., 2000; van Knegsel et al., 2007). In this case, equation [1] reduces to $\mathrm{EB}_{\text {body }}=\mathrm{z} \times \Delta \mathrm{BL}+\mathrm{y}$ $\times 0$, and equation [5] reduces to $0=\mathrm{k} \times(\Delta \mathrm{EBW}-$ $\triangle \mathrm{BL}$ ), and further to $\Delta \mathrm{BL}=\Delta \mathrm{EBW}$. Therefore, when $\mathrm{BP}$ change is zero, $\mathrm{EB}_{\text {body }}$ can be estimated using only $\mathrm{BW}$ measurements because in this situation $\mathrm{EB}_{\text {body }}=$ $\mathrm{z} \times \Delta \mathrm{EBW}$.

Although the $\mathrm{EB}_{\text {body }}$ method presented has the potential to provide on-farm energy balance measures, the present study should be regarded as a proof-of-concept rather than a definitive method. Several issues remain to be further explored. In particular, the smoothing method used for deriving the meal-related gutfill-free BW is not suitable for real-time usage. As on-farm applications already exist that employ real-time smoothing techniques (Nielsen et al., 2005), the development of a real-time $\mathrm{EB}_{\text {body }}$ method is feasible. Within the $\mathrm{EB}_{\text {body }}$ method, there are several constants that should not be regarded as universal; for example, the constants (a and b) for converting BCS to body fatness ( $\mathrm{g}$ of lipid/g of EBW) depend on the BCS scale being used. In the present study, we used the values 0.05 (a) and 0.10 (b) from (Friggens et al., 2007a). However, in a real-time 
model, it could be envisaged that these constants could be optimized locally by incorporating information from the local relationship between BCS and BW. Further, in a real-time model, using the previous measures in the time-series, it would be possible to determine cowspecific time points when rates of change in $\mathrm{BL}$ and $\mathrm{BP}$ shift from negative to positive (the energy requirement coefficients y and z differ according to whether deposition or mobilization of body tissues occurs).

It would be desirable to further evaluate the method on larger, independent data sets to confirm the robustness of the method to differences between breeds and parities, and in particular in relation to diet types. In this context, the 2 assumptions made in the present study concerning GF are of interest. We assumed that GF could be considered as having 2 components; namely, meal-related GF and RGF (Martin and Sauvant, 2010b) and then estimated the meal-related GF by quantile regression using the lower $20 \%$ quantile. The adequate removal of the influence of meal-related GF from the BW data is important, because failure to do so inevitably transfers this noise to the profiles of $\mathrm{EB}_{\mathrm{body}}$. Because differences in feed composition and differences due to prior feed intake both tend toward zero with time (Martin and Sauvant, 2010b), we also assumed that RGF was a constant proportion (0.26) of LFEBW. Simulation using different values suggested that these assumptions were reasonable, but it would be worth examining the robustness of these assumptions in detail using data from experiments specifically designed to examine these issues.

Finally, the present model estimated $\mathrm{EB}_{\text {body }}$ during the first 150 DIM, when energy consumption of the growing conceptus is negligible. However, if the full lactation were modeled, the weight of the gravid uterus would need to be subtracted from BW before calculation of $\mathrm{EB}_{\text {body }}$. The weight of the gravid uterus can be predicted for the entire gestation period, because equations for doing so already exist (NRC, 2001; Martin and Sauvant, 2010a).

\section{CONCLUSIONS}

A method for estimating the energy balance $\left(\mathrm{EB}_{\text {body }}\right)$ of individual cows based solely on frequent measurements of BW and BCS was developed and tested. The BW measurements were sequentially smoothed to derive milk- and meal-related GF-free BW, thus allowing $\mathrm{EB}_{\text {body }}$ to be estimated without requiring information on feed intake. The $\mathrm{EB}_{\text {body }}$ compared well with the traditional energy balance calculated from DMI and MY measures. This method has the potential to provide a valuable on-farm management tool without the necessity for measurements of DMI, feed composition, or
MY. Future work should focus on adapting the present method to allow real-time estimation of energy balance.

\section{ACKNOWLEDGMENTS}

This work was part of a project "In-line monitoring technology, biomarkers, sensor technology, risk management, and expert systems" funded by the Danish National Advanced Technology Foundation. The funding body had no involvement with this study. We thank the staff at DCRC for performing the BCS and Connie Middelhede (Department of Animal Science, Aarhus University, Tjele, Denmark) for help in making the raw weight data accessible.

\section{REFERENCES}

Azzaro, G., M. Caccamo, J. D. Ferguson, S. Battiato, G. M. Farinella, G. C. Guarnera, G. Puglisi, R. Petriglieri, and G. Licitra. 2011 Objective estimation of body condition score by modeling cow body shape from digital images. J. Dairy Sci. 94:2126-2137.

Banos, G., and M. P. Coffey. 2010. Genetic association between body energy measured throughout lactation and fertility in dairy cattle. Animal 4:189-199.

Bewley, J. M., and M. M. Schutz. 2009. Potential of Using New Technology for Estimating Body Condition Scores. Pages 23-38 in Proc. 18th Annual Tri-State Dairy Nutrition Conf., Ft Wayne, IN. Ohio State University, Columbus.

Cammell, S. B., D. E. Beever, J. D. Sutton, J. France, G. Alderman, and D. J. Humphries. 2000. An examination of energy utilisation in lactating dairy cows receiving a total mixed ration based on maize silage. Anim. Sci. 71:585-596.

Coffey, M. P., G. C. Emmans, and S. Brotherstone. 2001. Genetic evaluation of dairy bulls for energy balance traits using random regression. Anim. Sci. 73:29-40.

Ellis, J. L., F. Qiao, and J. P. Cant. 2006a. Evaluation of net energy expenditures of dairy cows according to body weight changes over a full lactation. J. Dairy Sci. 89:1546-1557.

Ellis, J. L., F. Qiao, and J. P. Cant. 2006b. Prediction of dry matter intake throughout lactation in a dynamic model of dairy cow performance. J. Dairy Sci. 89:1558-1570.

Emmans, G. C. 1994. Effective energy: A concept of energy utilization applied across species. Br. J. Nutr. 71:801-821.

Emmans, G. C., and I. Kyriazakis. 2001. Consequences of genetic change in farm animals on food intake and feeding behaviour. Proc. Nutr. Soc. 60:115-125.

Ferguson, J. D., D. T. Galligan, and N. Thomsen. 1994. Principal descriptors of body condition score in Holstein cows. J. Dairy Sci. 77:2695-2703.

Friggens, N. C., P. Berg, P. Theilgaard, I. R. Korsgaard, K. L. Ingvartsen, P. Lovendahl, and J. Jensen. 2007a. Breed and parity effects on energy balance profiles through lactation: Evidence of genetically driven body energy change. J. Dairy Sci. 90:5291-5305.

Friggens, N. C., G. C. Emmans, I. Kyriazakis, J. D. Oldham, and M. Lewis. 1998. Feed intake relative to stage of lactation for dairy cows consuming total mixed diets with a high or low ratio of concentrate to forage. J. Dairy Sci. 81:2228-2239.

Friggens, N. C., C. Ridder, and P. Lovendahl. 2007b. On the use of milk composition measures to predict the energy balance of dairy cows. J. Dairy Sci. 90:5453-5467.

Frigo, E., C. D. Dechow, O. Pedron, and B. G. Cassell. 2010. The genetic relationship of body weight and early-lactation health disorders in two experimental herds. J. Dairy Sci. 93:1184-1192.

Halachmi, I., P. Polak, D. J. Roberts, and M. Klopcic. 2008. Cow body shape and automation of condition scoring. J. Dairy Sci. 91:4444-4451. 
Hastie, T. J., and R. J. Tibshirani. 1990. Generalized Additive Models. 1st ed. Chapman \& Hall/CRC, Boca Raton, FL.

Ingvartsen, K. L., R. J. Dewhurst, and N. C. Friggens. 2003. On the relationship between lactational performance and health: Is it yield or metabolic imbalance that cause production diseases in dairy cattle? A position paper. Livest. Prod. Sci. 83:277-308.

Ingvartsen, K. L., and M. R. Weisbjerg. 1993. Jersey cows have a higher feed intake capacity and higher rate of passage than Friesian cows. Arch. Tierzucht. 36:495-498.

Koenker, R., and K. F. Hallock. 2001. Quantile regression. J. Econ. Perspect. 15:143-156.

Littel, R. C., W. W. Stroup, and R. J. Freund. 2002. SAS for Linear Models. 4th ed. SAS Institute Inc., Cary, NC.

Martin, O., and D. Sauvant. 2010a. A teleonomic model describing performance (body, milk and intake) during growth and over repeated reproductive cycles throughout the lifespan of dairy cattle. 1. Trajectories of life function priorities and genetic scaling. Animal 4:2030-2047.

Martin, O., and D. Sauvant. 2010b. A teleonomic model describing performance (body, milk and intake) during growth and over repeated reproductive cycles throughout the lifespan of dairy cattle. 2. Voluntary intake and energy partitioning. Animal 4:2048-2056.

Nielsen, N. I., N. C. Friggens, M. G. G. Chagunda, and K. L. Ingvartsen. 2005. Predicting risk of ketosis in dairy cows using in-line measurements of $\beta$-hydroxybutyrate: A biological model. J. Dairy Sci. 88:2441-2453.

NRC. 2001. Nutrient Requirements of Dairy Cattle. 7th ed. National Academy Press, Washington, DC.

Oldenbroek, J. K. 1988. The performance of Jersey cows and cows of larger dairy breeds on two complete diets with different roughage contents. Livest. Prod. Sci. 18:1-17.

R Development Core Team. 2011. R: A language and environment for statistical computing. R Foundation for Statistical Computing, Vienna, Austria. Accessed Nov. 29, 2011. http://www.R-project. org/.

Tedeschi, L. O., S. Seo, D. G. Fox, and R. Ruiz. 2006. Accounting for energy and protein reserve changes in predicting diet-allowable milk production in cattle. J. Dairy Sci. 89:4795-4807.

van Knegsel, A. T. M., H. van den Brand, J. Dijkstra, W. M. van Straalen, M. J. W. Heetkamp, S. Tamminga, and B. Kemp. 2007. Dietary energy source in dairy cows in early lactation: Energy partitioning and milk composition. J. Dairy Sci. 90:1467-1476.

Wright, I. A., and A. J. F. Russel. 1984. Estimation in vivo of the chemical composition of the bodies of mature cows. Anim. Prod. $38: 33-44$. 